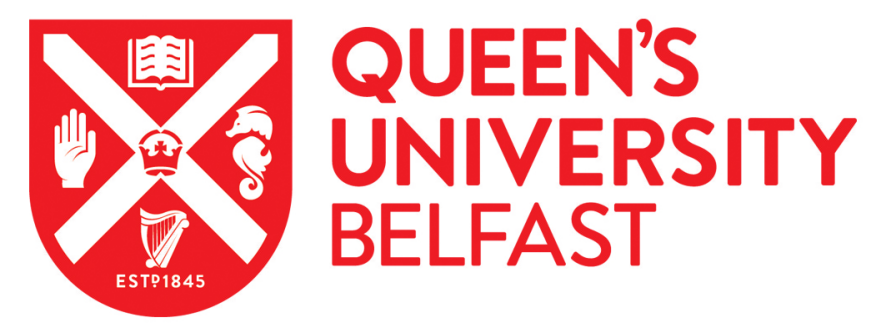

\title{
'A small cargoe for tryal': Connections between the Belfast and Philadelphia book trades in the later eighteenth century
}

O'Connor, M. (2011). 'A small cargoe for tryal': Connections between the Belfast and Philadelphia book trades in the later eighteenth century. In Books between Europe and the Americas: Connections and Communities, 16201860 (pp. 187-211). Palgrave/Macmillan. https://doi.org/10.1057/9780230305090

Published in:

Books between Europe and the Americas

Document Version:

Peer reviewed version

Queen's University Belfast - Research Portal:

Link to publication record in Queen's University Belfast Research Portal

\section{General rights}

Copyright for the publications made accessible via the Queen's University Belfast Research Portal is retained by the author(s) and / or other copyright owners and it is a condition of accessing these publications that users recognise and abide by the legal requirements associated with these rights.

Take down policy

The Research Portal is Queen's institutional repository that provides access to Queen's research output. Every effort has been made to ensure that content in the Research Portal does not infringe any person's rights, or applicable UK laws. If you discover content in the Research Portal that you believe breaches copyright or violates any law, please contact openaccess@qub.ac.uk. 
'A Small Cargoe for Tryal': Connections between the Belfast and Philadelphia Book Trades in the Later Eighteenth Century

\section{Michael O’Connor}

This chapter considers the possibility that print formed a transatlantic community by means of connections between the Belfast and Philadelphia book trades in the eighteenth century. ${ }^{1}$ The essay will explore the nature of these connections, examining the reasons for such interaction and assessing the impact of such bonds on the status of Belfast printing. ${ }^{2}$ While recent studies have mentioned the various connections between Irish booksellers and their counterparts in North America, primarily in places such as Philadelphia and New York for example, the extensive work of Richard Cargill Cole ${ }^{3}$ - attention has tended to fall upon the impact of such contacts on the American book trade and the emergence of a native reprint tradition. As such, there has been little consideration given to assessing the implications of these bonds upon Irish printing, especially printing outside of Dublin. This chapter will examine the balance of power between printing in Dublin and the Irish provinces and its subtle shift during the Revolutionary period because of these important colonial connections.

\footnotetext{
${ }^{1}$ I am indebted to delegates to the conference, 'Connected by Books: the Forging of Transatlantic Literary Communities', University of Essex, 2 Dec 2007, for their various suggestions, and also to recommendations offered by Moyra Haslett.

${ }^{2}$ In the following, 'printer' refers to those who personally, or through their employees, operated the printing press; 'publisher' alludes to those responsible, financially, for putting the book on sale although the word was not in frequent use until the nineteenth century; 'bookseller' denotes a seller of books, the individual responsible for the retail distribution of a work. The term 'bookselling' is used, however, in its eighteenth-century composite meaning to indicate not simply the sale of an item but also the printing, publication, sale and distribution of printed matter.

${ }^{3}$ Richard Cargill Cole, Irish Booksellers and English Writers 1740-1800 (London, 1986).
} 
The absence of copyright legislation in Ireland until 1801 was both a blessing and a curse for the Irish book trade. Freed from having to pay the price of copy, or of having to be subject to the exclusive publication rights set down by copyright, Irish printers were able to reprint London editions of texts, which in England only the copyright holder was permitted to print. This led to a thriving reprint industry in Ireland in which reprints were sold to both a domestic and international market, but it also created a book trade in which few original publications were published. Printing in Dublin - the centre of the Irish book - was consequently regarded as deficient when compared to London and its printers were viewed suspiciously, sometimes antagonistically, by their counterparts in London. Mary Pollard gives the following synopsis:

Considered merely as a reprinter of London books, the Dublin book trade looks like a pale and inferior reflection of that of London. As something of a phenomenon in its very rapid development in the eighteenth century, however, it deserves study in its own right, not in spite of its reprints but because its prosperity was largely based on them. ${ }^{4}$

With these words Pollard began her landmark study on Dublin printing in 1989, a study in which she defended the Dublin book trade against the established charges of piracy, marginality and of being fundamentally unsophisticated. In rejecting these commonly held assumptions of eighteenth-century Dublin printing, she traced the negative representation

\footnotetext{
${ }^{4}$ Mary Pollard, Dublin’s Trade in Books, 1550-1800 (Oxford, 1989): v.
} 
of the Irish book trade as having arisen from the complaints of mid-century English publishers, such as Samuel Richardson, whose vociferous criticism of Dublin printers as dishonest bootleggers passed largely unchallenged into history. ${ }^{5}$ She contested these accusations of piracy through giving examples of collaboration between the Dublin and London trades. 6

Without Pollard's work modern scholarship on the history of the Irish book would certainly have been poorer. She has made scholars sceptical of the inflated claims of British publishers, such as William Strahan and John Murray, with regards to the Irish trade and the impact of Irish reprints within an international context. For example, in October 1781 Strahan complained to the leading Edinburgh publishing-bookseller, William Creech about the damaging effects of Dublin reprints on his copyright profits: 'The Irish immediately reprint upon us in a cheap size and not only run away with the whole American Trade, but even import them, with Impunity, into all the Western Coast of Britain. Nor are we able, as you well know, to prevent this.' In the following month he stressed the dangers of Dublin reprinting, deeming it an 'illicit trade, which tears up our Property by the very Roots'.? While Irish reprints were sold for the most part to a domestic audience, they were sold also in Britain and in North America. It was with these latter two locations that British

\footnotetext{
${ }^{5}$ Ibid., pp. 66, 88-9; see also Cole, Irish Booksellers and English Writers, p. 11; Richard B. Sher, The Enlightenment \& the Book: Scottish Authors \& Their Publishers in Eighteenth-Century Britain, Ireland, \& America (Chicago, IL and London, 2006): 444, 497.

${ }^{6}$ Pollard, Dublin's Trade in Books, p. 66; see pp. 97-102 for a discussion of those Dublin publishers who entered into agreements with London copyright holders for reprint rights.

${ }^{7}$ Letters from Strahan to Creech (18 Oct and 20 Nov 1781), cited in Sher, The Enlightenment \& the Book, p. 448.
} 
publishers such as Strahan were particularly concerned and it is with regard to the colonial context that this chapter is chiefly focused.

British publishers, particularly those at work in the London trade, were keen to preserve the monopoly that they exerted upon the colonies in terms of the supply of books, a monopoly which was the result of a combination of factors. ${ }^{8}$ Trading legislation in the form of the Navigation Acts (which ensured that colonial commerce occurred with colonial and English vessels) and printing rights (exercised through legal monopolies on the publication of Bibles, prayers books, psalters and law books, which could only be undertaken by designated printers in England) resulted in the colonies being limited from the outset in terms of what they could print and with whom they could trade. Having little recourse other than to trade with English merchants and order books under patent from English suppliers, colonial contact with Britain from the seventeenth century onwards was a necessity. The fledging state of colonial printing for the greater part of the eighteenth century, the result of a shortage of capital and resources, was yet another important reason explaining colonial dealings with the English book trade.

\footnotetext{
${ }^{8}$ For the international trade in books see Giles Barber, 'Books from the Old World and for the New: The British International Trade in Books in the Eighteenth Century', Studies on Voltaire and the Eighteenth Century, 151 (1976): 219-24; Giles Barber, 'Book Imports and Exports in the Eighteenth Century', in Robin Myers and Michael Harris (eds.), The Sale and Distribution of Books from 1700 (Oxford, 1982): 9495; Stephen Botein, 'The Anglo-American Book Trade before 1776: Personnel and Strategies' in William L. Joyce, David D. Hall, Richard D. Brown, and John B. Hench (eds.), Printing and Society in Early America (Worcester, MA, 1983): 48-82; James Raven, 'The Export of Books to Colonial North America', Publishing History 42 (1997): 21-49; James Raven, London Booksellers and American Customers:

Transatlantic Literary Community and the Charleston Library Society, 1748-1811 (Columbia, SC, 2002).
} 
To begin with, colonial printers suffered from a range of difficulties, such as weak markets, tight credit, restive labour, poor transportation and a dispersed readership. ${ }^{9}$ The single greatest problem was the difficulty of obtaining basic manufacturing material. This resulted in high capital costs for printing in America. ${ }^{10}$ Generally, it proved less of a gamble for printers in North America to order books from abroad than to expend the capital in reprinting a work and run the risk of not recouping all costs involved in its publication. This was especially so if colonial printers were offered attractive discounts by London wholesalers.

Drawn by the potential for profit in supplying a colonial trade that was reliant upon it for the provision of books, booksellers and publishers in England actively sought out trading connections with colonial booksellers with the result that 'during the third quarter of the century, London wholesaling booksellers pursued the American market with great zeal'. ${ }^{11}$ While there is little doubt that the predominant source for books in America was England, book exportation did occur throughout the century in Scotland and Ireland. ${ }^{12}$ Books exported from Ireland were especially a source of concern for English booksellers. Since Irish printers were under no obligation to pay copyright fees, Irish reprinted editions sold more cheaply than the originals, significantly undercutting the prices of London

\footnotetext{
${ }^{9}$ John Bidwell, 'Part Two. Printers' Supplies and Capitalization' in Hugh Amory and David D. Hall (eds.), A History of the Book in America vol. I The Colonial Book in the Atlantic World (Chapel Hill, NC, 2007): 163.

${ }^{10}$ Raven, London Booksellers and American Customers, p. 6.

${ }^{11}$ James Raven, 'Part Three: The Importation of Books in the Eighteenth Century', in Amory and Hall (eds.), A History of the Book in America, p. 188.

${ }^{12}$ For a useful discussion of the Scottish trade in books to North America, see Warren McDougall, 'Scottish Books for America in the Mid 18th Century' in Robin Myers and Michael Harris (eds.), Spreading the Word: The Distribution Networks of Print 1550-1850 (Winchester and New Castle, DE, 1990): 21-46.
} 
editions. This was further compounded by the fact that they were produced on less expensive paper and in smaller sizes such as duodecimo, which required less paper than the larger sizes. ${ }^{13}$ Unsurprisingly, London booksellers and publishers grew alarmed at the ability of Irish printers to penetrate the colonial market with inexpensive reprints which could threaten their monopoly. The anxieties of Strahan mentioned above are emblematic of this alarm.

Strahan's claims that Irish reprints were doing untold damage to London publishers appear, however, to been exaggerated, which leads one to evaluate the actual significance of Irish reprints within an international context, of which the example of Belfast's connections with Philadelphia serves as a very useful case study. In his investigation of transatlantic publishing, Richard B. Sher has conveyed a more tempered picture, arguing that, contrary to the assertions of Murray and Strahan, British books were not always reprinted in Ireland, but he concedes that the opinions of London publishers and booksellers, while overstated, were nonetheless 'grounded in reality'. He insists that the reprint trade carried out in Dublin was in fact the axis upon which the transmission of Scottish Enlightenment texts - by authors such as David Hume and Adam Smith - across the Atlantic pivoted. ${ }^{14}$ He writes:

\footnotetext{
${ }^{13}$ See Colm Lennon, ‘The Print Trade, 1700-1800' in Raymond Gillespie \& Andrew Hadfield (eds.), The Oxford History of the Irish Book vol. 3 The Irish Book in English 1550-1800 (Oxford, 2006): 84; Pollard, Dublin's Trade in Books, pp. 110-18; James Phillips, Printing and Bookselling in Dublin, 1670-1800 (Dublin, 1998): 285-286.

${ }^{14}$ Scottish Enlightenment texts were reprinted extensively in Ireland. This needs to be offered with the caveat, however, that Scottish Enlightenment books made up only a small fraction of the total amount of books reprinted in late eighteenth-century Dublin. Sher, The Enlightenment \& the Book, p. 448.
} 
Dublin was the hinge on which the Atlantic dissemination for Enlightenment books turned. Whether they were making cheap editions or attempting to surpass the British originals they were copying, and whether their products were ultimately bound for readers in Ireland, the Americas, Britain or the Continent, the Dublin reprinters were above all else appropriators of culture ... their actions contributed almost as much as ... [the] other major publishers of new books in London and Edinburgh to the creation and diffusion of the Scottish Enlightenment as an Atlantic cultural phenomenon. The Scottish Enlightenment was crossing the Atlantic, and Irish booksellers were among its principal agents. ${ }^{15}$

In offering this assessment of the Irish trade in its transatlantic dimension, he makes a case, rather convincingly also, that those at work in Dublin were not simply 'copy-and-paste' printers, hastily copying the latest London edition of a text, with no regard for what was contained therein or how it was presented, but were actually vital cultural agents for the promulgation of the Scottish Enlightenment within America.

Such a reading tends to endow Dublin booksellers with a vast and impressive impact upon the North American colonial market. This is not, however, revealed by the official Irish statistics of its book exports to America throughout the eighteenth century: Ireland was prohibited from selling books and other goods across the Atlantic for the first 80 years of the century. There is, however, evidence that books were sent from Ireland as early as the 1720s. Custom House records consequently only reveal a fraction of the picture

\footnotetext{
${ }^{15}$ Sher, The Enlightenment \& the Book, p. 502.
} 
and the data does not account for the lively invisible trade that occurred in the smuggling of books throughout the century. ${ }^{16}$

Since Irish books sent to North America prior to 1780 were subject to seizure, the smuggling of books was not without its own risks. Illegal books subsequently incurred added expense and delay and required notable vigilance for the colonial bookseller attempting to circumvent detection of the contraband cargo by the authorities. Such obstacles notwithstanding, colonial booksellers were evidently enthusiastic about ordering cheap Irish reprints. And in the aftermath of 1780 when Irish book exports were made legal, books were shipped across the Atlantic from Ireland with increased regularity and vigour. ${ }^{17}$

Both Boston and New York featured prominently in the Irish book trade to North America, but the most significant and sustained connections were with booksellers in Philadelphia. The David Hall correspondence presents one case study of such print networks. Hall was probably the single most important importer of books in the colonies by mid-century. Between 1748 and 1772 his imports, it is estimated, exceeded £40,000 sterling. ${ }^{18}$ While the main source of his supply was from London, Hall also imported material from Dublin and Belfast. Richard C. Cole’s work has made irrefutable the vigour of such trading connections between booksellers in Philadelphia with those in Ireland. In Irish Booksellers and English Writers 1740-1800 he has shown that printers and booksellers in Dublin disseminated the works of the major British writers of their time and enhanced the audience for these writers not only in Ireland and Britain but in America in

\footnotetext{
${ }^{16}$ Cole, Irish Booksellers and English Writers, p. 4; Pollard, Dublin’s Trade in Books, pp. 140-3.

${ }^{17}$ Pollard, Dublin's Trade in Books, p. 149.

${ }^{18}$ James Green, 'Part One: English Books and Printing in the Age of Franklin', in Amory and Hall (eds.), A History of the Book in America, p. 278.
} 
places such as Philadelphia and New York. ${ }^{19}$ The research of Sher and Cole has shown that Irish booksellers were the most significant distributors of English and Scottish authors and were responsible for the diffusion of this material to an American audience within the second half of the century. J.D. Fleeman has observed that Irish booksellers 'contributed to the dissemination of Enlightenment ideas and judgments, by distributing books to readers on both sides of the Atlantic, and it is particularly as the distributors of books that the Irish trade warrants close attention. ${ }^{20}$ The connections that were created and fostered as a result of this trade enabled the distribution of books; they also ensured that Enlightenment ideas were transmitted to the shores of America.

While the connections between Philadelphia and Dublin booksellers have been noted in some detail - for example, in the studies by Cole and Sher - there has been little attention given to the transatlantic links between Belfast and Philadelphia. This chapter seeks to redress this imbalance by taking as its chief case study the relationship between the Belfast and Philadelphia book trades in the period 1763-76. Studies by McDougall and Cole have referred briefly to Belfast's links with Philadelphia, with the latter emphasizing the economic advantages of such transactions. ${ }^{21}$ Cole has represented the purposes of such links as an opportunity for colonial booksellers to have acquired quality Irish reprints at affordable prices. The cheapness of Irish reprinted editions would easily have appealed to the business sensibilities of colonial booksellers who, if David Hall is representative,

\footnotetext{
${ }^{19}$ Cole, Irish Booksellers and English Writers, p. ix.

${ }^{20}$ J. D. Fleeman, 'Book Review: Irish Booksellers and English Writers 1740-1800 by R. C. Cole', The Review of English Studies, New Series, 38, 152 (Nov, 1987): 568.

${ }^{21}$ Cole, Irish Booksellers and English Writers, p. 41; McDougall, 'Scottish Books for America in the Mid 18th Century', p. 31.
} 
demanded of their London agent that books be priced 'as reasonable as you can', citing the scarcity of money in Philadelphia and the cheapness of Irish and Scottish books imported into the city as making low-cost prices from suppliers a necessity. ${ }^{22}$

While this economic consideration was undoubtedly an important reason why colonial booksellers ordered Irish printed books, the cultivation of such links was actually heavily influenced by and utilized for other reasons than the cheapness of Belfast reprints. Philadelphia booksellers imported Belfast books seeking to appeal specifically to pockets of Ulster-Scottish communities in the colonies who wished to retain cultural links with home. And, in turn, Belfast printers and booksellers wished to supply that market, all the while utilizing contacts with Philadelphia booksellers to access political and polemical material which was unavailable outside North America and which would augment the capabilities of Belfast printing. This was especially important during the years of the Revolution when Belfast supported the cause of America, and when having access to the newest American tract and pamphlet offered printers in the town a distinct edge over their Dublin competitors. The associations with Philadelphia, therefore, during this period were partly driven by the demands of the Belfast book-buying public and by their insatiable appetite for political matter relating to the American conflict.

The outcome of such interaction was thus quite significant. Indeed, these connections meant that the supremacy of Dublin printing was in small ways changing in tandem with Belfast contacts with Philadelphia. Moreover, colonial booksellers sought to

\footnotetext{
${ }^{22}$ David Hall, letter to William Strahan, 21 Mar 1752 in Letterbook 4, Commencing Anno 1750 (17501755), American Philosophical Society, B. H142.1-3: David Hall Papers, (hereafter DHP).
} 
exploit the links with Belfast not simply to access books but newspapers also, as the foreign news sections of colonial newspapers were vitally important. The result therefore was the utilization of the Atlantic as a communication 'superhighway' in this period and the cultivation of linked print communities in the two locations.

Firm ties between Belfast and Philadelphia had been established by the 1760s. During this decade books printed in Belfast, the most important town in the north of Ireland, were available in Philadelphia and were requested by booksellers there. These connections, however, are not revealed in the names of subscribers of Belfast editions but disclosed in booksellers' correspondence. From the available evidence, it is apparent that the connections uniting the two book trades were created in four ways: (1) by relatives of Belfast printers working in Philadelphia; (2) by apprentices who had formerly worked in Belfast moving to Philadelphia to work in its book trade; (3) by Philadelphia booksellers with no established connection with Belfast but who were keen to initiate trade; and (4) by emigrants bringing cherished books printed in Belfast with them to the New World. Chronologically, the first three phases occurred in quick succession, whereas the impact of emigrants upon the creation of such trading connections is difficult to gauge and therefore can only problematically be placed within this timeline of events. The presence of Irish emigrants is indeed likely to explain how Belfast printed books were available in North America before Belfast printers had made connections with colonial booksellers. By 1770 four Belfast reprints, three of which were works of religious devotion, had been obtained by The Library Company of Philadelphia. These four texts were John Bunyan, Grace Abounding to the Chief of Sinners ... (Belfast, [s.n.], 1714); The Gazetteer; Or the 
Newsman's Interpreter (Belfast, Francis Joy, 1740); Edward Fowler, The Design of Christianity (Belfast, Samuel Wilson \& James Magee, 1741); and Jacques Bénigne Bossuet, An Introduction to, or a Short Discourse Concerning, Universal History (Belfast, Wilson \& Magee, 1742). ${ }^{23}$ These examples demonstrate that Belfast books found themselves in Philadelphia possibly before Magee (and indeed other Belfast printers) had established firm contacts with booksellers there. It is probable that these works had been transported by Belfast men and women who had come to settle in the New World, which was not an uncommon means by which new books arrived in the colonies. From the available evidence, the initial contact that was established appears to have involved Belfast printers and their relatives at work in Philadelphia.

This was the case with James Magee (1707-97). Magee, whose career spanned 1735-91, was the chief Belfast printer, bookseller and publisher throughout the century, being the foremost printer in the town of plays, sermons, chapbooks and political tracts and pamphlets. Throughout the period of Volunteer associations in the 1780s he became the chief Irish printer of Volunteer sermons. He was a pivotal figure in terms of the printing and supply of books throughout the north of Ireland; his publications also retailed in Dublin and some sold as far as Philadelphia. The sale of his texts in North America occurred in the 1760s, although it is likely to have begun in the previous decade, and involved two of James's blood relations who lived there. Magee’s brother Thomas worked in Philadelphia

${ }^{23}$ The Charter, Laws, and Catalogue of Books, of the Library Company of Philadelphia (Philadelphia, PA, B. Franklin \& D. Hall, 1757): 112; The Charter, Laws, and Catalogue of Books, of the Library Company of Philadelphia (Philadelphia, PA, Joseph Crukshank, 1770), 'Books in Duodecimo G', nos. 150 \& 527;

'Books in Octavo U', no. 128. 
as a publisher and bookseller from 1764 to 1769 . He worked at the Bible-in-Heart in 1769 and acted as the administrator of Andrew Steuart's estate when Steuart died tragically in 1769. ${ }^{24}$ Nathaniel, possibly another brother, who lived near Thomas in Arch Street in 1753, was commander of the ship Alexander of Philadelphia that in August 1757 sailed from Belfast to the American city carrying passengers, servants and redemptioners. Nathaniel's name also appeared on the 'outwards' and 'inwards' entries for the Custom House, Philadelphia in that year. ${ }^{25}$ His role in the process of importing Belfast books appears more ambiguous than Thomas but it seems likely that he was transporting books to Philadelphia, as well as indentured servants, in 1757. Unfortunately, no papers or accounts exist for James Magee so it is not possible to know the precise details of his arrangement with Thomas and Nathaniel, or indeed to know the actual titles that were sent from Belfast. But the arrangement was certainly upon solid foundations given the family connections between the Magees, confirming Raven’s assertion that in terms of the transatlantic trading of books 'the strongest bonds were familial'. ${ }^{26}$

Belfast’s initial trading connections with Philadelphia may have been instigated by means of such important fraternal bonds, but the links with booksellers in that city soon operated beyond the established network of family contacts. Former employees of the Belfast print trade, who worked in Philadelphia as printers and booksellers, were next utilized as a means of penetrating further into the colonial market. Magee was well placed

\footnotetext{
${ }^{24}$ Glenn H. Brown and Maude O. Brown, A Directory of the Book-Arts and Book Trade in Philadelphia to 1820 (New York, 1950): 79; Pennsylvania Gazette (hereafter PG) 19 Oct 1769.

${ }^{25}$ Belfast News-Letter (hereafter BNL), 1 Jul 1757; PG, 5 Apr 1753; 3 Mar 1757; 17 Nov 1757.

${ }^{26}$ Raven, 'Part Three’, p. 189.
} 
to do this. He trained at least two apprentices, Andrew Steuart and Hugh Gaine, both of whom established themselves as important printers, in Philadelphia and New York respectively. Steuart worked in Philadelphia in the 1760s: he produced 140 imprints between 1758 and 1769. Steuart established Laetitia Court in 1758 and moved into various premises in the seven years that he lived in Philadelphia. Thomas notes that about 1764, Steuart went to Wilmington, North Carolina, leaving some types and his bookshop in the care of Thomas Magee and that of his apprentice Joseph Cruikshank. ${ }^{27}$ James Magee supplied Steuart with chapbooks throughout this period and the links with his former apprentice remained long after Steuart had emigrated from Ulster. ${ }^{28}$ This is a view supported by Neuburg, who argues that Magee was the source of much of Steuart's imported chapbook material. ${ }^{29}$ Magee's other apprentice also preserved his connections with Belfast. Hugh Gaine (1726-1807), who arrived in New York in 1745 and worked in that city as a printer, reprinted a Belfast publication in 1776 (The Young Clerk's Vade Mecum: Or, Compleat Law-Tutor) and was a substantial retailer of Irish printed publications. His catalogue of 1792 lists more than 500 titles published in Ireland. ${ }^{30}$

\footnotetext{
${ }^{27}$ Cole, Irish Booksellers and English Writers, p. 44; Brown and Brown, A Directory of the Book-Arts and Book Trade in Philadelphia to 1820, p. 114; Isaiah Thomas, The History of Printing in America with a Biography of Printers \& an Account of Newspapers, Marcus A. McCorison (ed.) (New York, 1970): 386. ${ }^{28}$ A catalogue of chapbooks, sold by Steuart and placed as an advertisement leaf in one of his publications (Robert Russel's Seven Sermons, 1763) offers a list of titles that are strikingly similar to the chapbooks printed and sold by Magee, and which he also advertised in his reprint of Seven Sermons, possibly in 1750. The chapbook titles that are common to both are considerable, adding force to the view that Steuart was selling material which had been imported from Magee.

${ }^{29}$ Victor E. Neuburg, 'Chapbooks in America: Reconstructing the Popular Reading of Early America', in Cathy N. Davidson (ed.), Reading in America Literature \& Social History (Baltimore, MD and London, 1989): 87-8.

${ }^{30}$ Cole, Irish Booksellers and English Writers, p. 43.
} 
In addition to Steuart, there were other members of the Philadelphia print trade who had formerly worked in Belfast. These contacts potentially created rich possibilities for individuals such as Magee who wished to enter the colonial market. John Dean, for example, who learned bookbinding in Belfast and Dublin and practised that trade along with bookselling in Philadelphia in 1765 and from 1775 until 1779. Also, John Reader, an English papermaker who worked in James Blow's firm in Belfast before he joined the Philadelphia book trade in $1768 .^{31}$ It would certainly have been commercially advantageous for booksellers in North America, such as Steuart or Gaine, to buy cheap Irish reprints. Copyright legislation did not apply to the colonies and in this respect mirrored the Irish trade. ${ }^{32}$ If we consider that it was more practical and cost effective to import books, especially if a colonial bookseller knew that he had a small and select number of buyers, it appears logical that Steuart should request books from his former master. Indeed, colonial booksellers often imported single titles of works for individual customers, indicating the potential losses that they would incur through reprinting a work for such a low readership. ${ }^{33}$ Rosalind Remer has argued such, observing that 'colonial markets were not highly developed or diverse, and importing a few copies of a book cost less than producing a whole edition locally'. ${ }^{34}$ Moreover, since bookbinders were scarce in the colonies and binding was even more expensive there than in London - David Hall gave explicit and repeated instructions to his British agents always to send books bound - cheap

\footnotetext{
${ }^{31}$ Ibid., pp. 45, 46.

${ }^{32}$ Copyright was extended to Ireland in 1801, while the American Copyright Act of 1790 protected only American writers and British writers were not protected until the Chace Act of 1891.

${ }^{33}$ For an example of this practice see David Hall, letter to William Strahan, 3 Sep 1764 in Letterbook 3, Commencing Anno 1764 (1764-1767) DHP.

${ }^{34}$ Rosalind Remer, Printers and Men of Capital: Philadelphia Book Publishers in the New Republic (Philadelphia, PA, 1996): 12.
} 
Irish editions, which were sent bound to the American colonies, offered a number of economic advantages for the colonial bookseller. ${ }^{35}$ Colonial booksellers, particularly those who had contacts with printers in Ireland, are thus likely to have taken advantage of those connections in order to access books at competitive prices.

While this economic explanation has been the predominant view to account for the importation of Irish books by colonial booksellers, the example of David Hall's association with the Belfast print trade complicates this straightforward perspective and confirms that colonial booksellers were involved with Irish printers and booksellers for reasons more diverse than the cheapness of Irish reprints. ${ }^{36}$ On 4 February 1766, Hall wrote to Magee requesting a small parcel of books, 'forty or fifty Pounds Value', which he hoped would mark the beginning of business between the two. ${ }^{37}$ In writing to Magee, Hall stipulated the titles and authors that he wanted, mainly works of religious devotion (including favourites such as Bunyan, Baxter and Fox), an assortment of chapbooks (with Hall insisting 'there should be a good Variety, and the more on the Droll and the merry strain the better'), plays, as well as 'Two or three Reams of Ballads - and any thing else you may think will answer'. Hall’s choice of titles, indicating books which were perennially popular and inexpensive, was well suited to the kinds of material printed by Magee. It drew directly upon Magee's strengths as an important reprinter of chapbooks and devotional works. The titles ordered

\footnotetext{
${ }^{35}$ Robert D. Harlan, 'David Hall's Bookshop and its British Sources of Supply', in David Kaser (ed.), Books in America's Past: Essays Honouring Rudolph H. Gjelsness (Charlottesville, NC, 1966): 6.

${ }^{36}$ The cheapness of Irish reprints has been regarded as the main motivation as to why colonial booksellers imported this material. For example, see Pollard, Dublin's Trade in Books, 163; Cole, Irish Booksellers and English Writers, pp. 191, 198.

${ }^{37}$ David Hall, letter to James Magee, 4 Feb 1766 in Letterbook 3, DHP.
} 
could easily have been accessed by a diverse market of readers, including those undergoing religious instruction, students and children. ${ }^{38}$

While the letter implies that this was the first correspondence between Hall and Magee, he was evidently familiar with Magee’s publications, revealing 'I have, at different times, bought some Books of yours from your Brother here, of which a Parcel lately arrd [arrived] and shall pay him for them next Month'. Hall hoped that his acquaintance with Thomas Magee would allay any anxieties the Belfast printer might have in striking up business with someone who was unknown to him. The initial order was deliberately low, being 'a small Cargoe for Tryal', with Hall intending it as a test for how the envisaged trade with Magee would fare. Owing to the hazardous and expensive nature of oceanic transportation, Harlan notes, American buyers preferred placing infrequent and large orders to frequent and small ones. ${ }^{39}$ Therefore, if the order placed with Magee proved satisfactory to Hall, further orders of greater amounts, one imagines, would have been requisitioned by the Philadelphia bookseller.

Magee's answer to this letter has not been preserved, so it is not possible to determine the full extent of his dealings with Hall. Prior to 1766, however, when he had first written to Magee, Hall had received shipments from other Belfast booksellers. His account books show evidence of his having received parcels of books from Belfast from 1762. ${ }^{40}$ It is certain that consignments of Belfast Bibles from David Hay had been sent to

\footnotetext{
${ }^{38}$ For a useful discussion of the kinds of books read by children and students in colonial America see E. Jennifer Monaghan, Learning to Read and Write in Colonial America (Amherst, MA, 2005): 302-332. ${ }^{39}$ Robert D. Harlan, 'William Strahan's American Book Trade, 1744-76', The Library Quarterly, 31 (1961): 240.

${ }^{40}$ See David Hall, Account Current Book, Commencing Anno 1748-[1768] DHP.
} 
Hall from 1761 to 1764; these had been instigated by John Balfour of Edinburgh. One of these shipments in 1763 was ill-fated - the Bibles were seized by Customs in Carlingford. Hall's letter to the Edinburgh publishing partnership of Hamilton and Balfour on 3 March expressed his chagrin. He bemoaned that this trade had caused him 'great Delay' and added expense - he had to pay £1 14s. 6d. for their seizure. The books 'were so Slender' and had been 'so ill packed' that he was surprised he 'got one Half of them'. ${ }^{41}$

The various nuisances and impediments caused by Hall's commerce with Belfast were, it should be noted, not unusual, for the process of book importation involved many potential difficulties. Colonial booksellers could, and did, encounter high pricing with their suppliers and errors in their orders. Financially also, booksellers had to pay costs other than the price of the books shipped, including interest upon the freight of goods. ${ }^{42}$ The actual transportation of the material was not without its attendant dangers. Shipments could be delayed if vessels sprang a leak, and readers often had to wait for extended periods before their books had made the expansive journey across the Atlantic. ${ }^{43}$ Poor packing and damp conditions on board caused damage to books, including mildew and harm to gilding. As a result, booksellers such as Hall gave specific and repeated instructions for care to be taken 'in getting the Books well packed up’, with each work secured by having pieces of paper wrapped round it. ${ }^{44}$ Colonial booksellers were only too aware of the potential problems that could occur, but importing Hay’s Bibles from Belfast throughout this period caused

\footnotetext{
${ }^{41}$ David Hall, letter to Hamilton \& Balfour, 3 Mar 1763 in Letterbook 2, Commencing Anno 1759 (17591764) DHP; letter to Balfour, 20 Nov 1764 in Letterbook 3, DHP.

${ }^{42}$ David Hall, letter to Johnson and Unwin, 9 Aug 1759 in Letterbook 2, DHP.

${ }^{43}$ Ibid., 21 Aug 1759; letter to Hamilton and Balfour, 2 Jul 1760 in Letterbook 2, DHP.

${ }^{44}$ For example, David Hall, letter to Hamilton and Balfour, 22 Dec 1760 in Letterbook 2, DHP; letter to William Strahan, 2 Apr 1761 in Letterbook 2, DHP; letter to Alexander Kincaid, 17 Dec 1765 in Letterbook 3, DHP.
} 
particular problems. The seizure of Bibles in 1763 caused added delay and expense, and with an earlier shipment in 1761, the Bibles initially arrived with no invoice, leaving Hall 'at a Loss how to Sell them' ${ }^{45}$ His subsequent decision to write to Magee suggests Hall was sufficiently impressed by Magee's publications for him to seek out the Belfast printer and bookseller, despite his unfortunate experiences with the town trade in the past.

This reading of events, however, is only partially accurate since Hall's decision to order books from Belfast in 1766 was affected by a number of other factors, not least of which was the current state of his relationship with his longstanding London supplier. It cannot be regarded as accidental that Hall should have written to Magee during a period in which relations between the Philadelphia bookseller and Strahan, his London wholesaler, were extremely fraught. Hall's letters at this time document his frustration, noting his many complaints against Strahan, such as repeated errors with orders, inexact invoices and Strahan's frequent divergence from Hall's directives. ${ }^{46}$ The latter point is a particularly salient one, with Hall feeling that his London contact was not as assiduous as he ought to be, leading him to remonstrate forcibly against Strahan in 1761 by asking 'what is the Matter you are not more Careful in finding me the Court and City Registers, and all new Pamphlets ... I have lately told you, be more exact in these Matters' ${ }^{47}$ Far from improving, the situation actually worsened when in October 1763 Hall forbade Strahan 'for the future, to send any Thing but what is Ordered', insisting that 'you remember what I say' and

\footnotetext{
${ }^{45}$ David Hall, letter to Hamilton and Balfour, 20 Jul 1761 in Letterbook 2, DHP.

${ }^{46}$ See David Hall, letters to William Strahan, 9 Aug 1759; 6 Dec 1760; 2 Apr 1761 \& 4 Nov 1761 in Letterbook 2, DHP.

${ }^{47}$ David Hall, letter to William Strahan, 2 Apr. 1761 in Letterbook 2, DHP.
} 
threatening 'if you do send without Order, I shall be obliged to return them, without opening'. ${ }^{48}$

Feeling dissatisfied with Strahan’s service, Hall sought to explore other bookselling contacts in both Scotland and Ireland in the 1760s: he wrote to initiate trade with Alexander Kincaid of Edinburgh in March 1764 and Magee of Belfast in February 1766. One can surmise that Hall was seeking a longstanding business relationship with another contact, a relationship which he intended to be more substantial than the occasional order. More than this, Hall may even have been looking to abandon his associate in London completely and switch to another connection more agreeable to his bookselling needs. By 1767 he was feeling particularly vulnerable. In a letter to Strahan in November, he complained that in his capacity both as a bookseller and as agent for the Library Company - he had been ordering their books since May 1763 - his reputation was being injured by orders which had not arrived, and he reiterated an observation which he had made formerly, that Strahan was too preoccupied with other business to tend to 'such small Matters' as him. ${ }^{49}$

At this extremely sensitive juncture, when Hall began reassessing his contacts and suppliers, the Philadelphia bookseller chose to instigate business with Magee, recognizing him as an attractive prospect. This was surely a transformative moment in Hall's career, at which he was willing to unfetter himself from dependence on Strahan, perhaps even forsake the relationship with him, in favour of other connections, including a printer and bookseller who worked not in London but in Belfast.

\footnotetext{
${ }^{48}$ Ibid., 11 Oct 1763.

${ }^{49}$ David Hall, letters to William Strahan, 14 May, 1763 in Letterbook 2 and 16 Nov 1767 in Letterbook 3, DHP.
} 
This is critically important, not simply owing to what it reveals about the fractious Hall-Strahan relationship at this period, but because it also provides a vital context stressing the significance of Magee within the international book trade. In the figure of Magee, Hall glimpsed a potential supplier who was extremely well placed to cater to his bookselling needs. Firstly, a network of contacts had hitherto been established which involved James in Belfast and his brother Thomas (and possibly Nathaniel also) in Philadelphia. This may have been established from as early as 1753 when there is evidence of both Thomas and Nathaniel living in Philadelphia, but it is certain that Magee's books were sold there from 1766. The quality of his books, moreover, may have been an added selling point. His publications were singled out for praise by the travel writer Richard Twiss in A Tour of Ireland in 1775 (London, 1776) who remarked, 'A few books have been printed in Belfast, by one James Magee, in a much neater manner than in any other part of Ireland, both as to the beauty of the types, and the fineness of the paper. ${ }^{50} \mathrm{~A}$ similar point is suggested by Sher, who has argued that while Irish reprints were produced in formats smaller than the London edition, for reasons of economy, these editions were by no means ‘quick and dirty’. These editions were actually seeking to challenge London editions of texts in their presentation, format and typography. ${ }^{51}$ Given Magee's prominence as a printer and bookseller in Ireland, the diversity of material that he produced and the obvious recognition from his editions that he was a craftsman, it is not surprising that colonial booksellers -

\footnotetext{
${ }^{50}$ Richard Twiss, A Tour in Ireland in 1775 (London: printed for the Author; and sold by J. Robinson, in New Bond-Street; J. Walter, at Charing-Cross; G. Robinson, in Paternoster Row; \& G. Kearsley, in Fleetstreet, 1776): 78.

${ }^{51}$ Sher, The Enlightenment \& the Book, pp. 497-502.
} 
particularly those who had familiarity with his publications, such as Hall - expressed an interest in establishing business with him.

Hall had other motivations, however, in singling Magee out. This was a period in which he actively sought access to provincial newspapers from England, Scotland and Ireland in order to furnish the foreign intelligence section of his Pennsylvania Gazette. ${ }^{52}$ In 1766 he asked Strahan to use his connections in order to acquire Irish newspapers for him. ${ }^{53}$ Keen to secure papers particularly from Belfast and Derry, Hall's decision to contact Magee must have been, in some measure, driven by this desire. His eagerness to acquire provincial newspapers was foremost in these years, in which he repeatedly requested and cajoled his various contacts in order that his newspaper could be as current as possible with the latest international news. ${ }^{54}$

This quest for Irish newspapers, particularly newspapers from the north of Ireland, was undoubtedly related to the expanding population of Ulster-Scots settlers in North America, for whom news of Ulster, as well as publications from Belfast, would have been especially resonant. It has been estimated that in the years between 1700 and 1776 at least 200,000 Presbyterians left Ulster, the greater number of whom established themselves in Philadelphia and New York. So significant was this migration that Kerby has noted that 'both in size and in relative proportion, Ulster emigration far overshadowed all other

\footnotetext{
${ }^{52}$ See for example, letter to Alexander Kincaid, 17 Dec 1765 and letter to William Strahan, 7 Jun 1766 in Letterbook 3, DHP.

${ }^{53}$ David Hall, letter to William Strahan, 7 Jun 1766 in Letterbook 3, DHP.

${ }^{54}$ For example, David Hall, letter to Alexander Kincaid, 17 Dec 1765 in Letterbook 3, DHP; letter to William Strahan, 7 Jun 1766 in Letterbook 3, DHP.
} 
population movements from Ireland to colonial America’ ${ }^{55}$ This group was also the most likely to preserve its connections, both familial and cultural, with home: 'Although Anglicans, like Catholics, tended to emigrate and assimilate as individuals, Dissenters transplanted communal and familial networks, retained relatively close ties to Ireland, and remained culturally distinct. ${ }^{56}$ Hall's selection of Magee as a bookselling contact was an obvious means of targeting this audience since many of Magee's reprints were Scottish, and among these there was a strong emphasis on Dissenting tracts and sermons. ${ }^{57}$ These books, moreover, were printed in a town that possessed a strong Scottish element, thereby underscoring the closeness of the connections with Scotland. ${ }^{58}$ It would have been evident to Hall from Magee's publications that Magee could usefully target this community.

Magee’s supply of Belfast printed books to his brother in Philadelphia ought to be understood therefore in this context: as a means of supplying material to a growing audience of expatriates who wished to preserve the special bond with home. Evidently, Hall also wished to engage himself in that process, indicated by his desire to obtain Magee’s publications, as well as newspapers from Ulster. But if Hall was enthusiastic about pursuing this specific market, he was not alone. Scottish and Irish reprints had been sold in Philadelphia from as early as the 1750s and, if Hall is to be believed, imported in

\footnotetext{
${ }^{55}$ Kerby A. Miller, Emigrants and Exiles: Ireland and the Irish Exodus to North America (New York and Oxford, 1985): 137, 153.

${ }^{56}$ Ibid., p. 150.

${ }^{57}$ For example, throughout his career Magee consistently reprinted sermons by the Scottish Seceding brothers, Ralph and Ebenezer Erskine, doubtless resonating with Dissenters and Seceders in Ulster who looked to Scotland as their mother church.

${ }^{58}$ W. H. Crawford, 'Ireland: Small Towns in Ulster' in Peter Borsay and Lindsay Proudfoot (eds.), Provincial Towns in Early Modern England and Ireland: Change, Convergence and Divergence, Proceedings of the British Academy, 108 (Oxford, 2002): 116-17.
} 
considerable number. He spoke of 'a great many Books ... from Ireland and Scotland'. ${ }^{9}$ It is likely that Hall was not overemphasizing the situation; the demand for books from Ulster is further suggested by the incidence of American reprintings of Belfast books in the succeeding years. These texts were reprinted in Philadelphia and New York, as well as Salem, Massachusetts in the 1770s, a persuasive indicator of the colonial market for Belfast material. ${ }^{60}$ There was a particular emphasis on schoolbooks and works of instruction. A Belfast primer (spelling book) written by schoolmaster John Manson and printed in the town about 1760 was reprinted in Philadelphia by John Dunlap in 1770, although that date is open to question. ${ }^{61}$ And in New York, Hugh Gaine, the former apprentice of Magee, reprinted The Young Clerk's Vade Mecum: Or, Complete Law-Tutor in 1776, the work being printed in Belfast. ${ }^{62}$ In both of these cases Belfast editions were reprinted by printers who had formerly lived in Ulster (Strabane and Belfast respectively). This suggests that there were readers in North America who wished to preserve the cultural links with home.

These connections with Belfast were still being used as selling points in American reprinted editions at the turn of the century. For example, publications written by Belfast authors were reprinted in Philadelphia and Wilmington in 1795 and 1798 respectively and these American reprints highlighted the Belfast heritage of the authors. Laws and Usages Respecting Bills of Exchange, and Promissory Notes was printed for T. Stephens by F. \&

\footnotetext{
${ }^{59}$ See David Hall, letter to William Strahan, 21 Mar 1752 in Letterbook 2, DHP.

${ }^{60}$ For example, John Nelson's A Letter to the Protestant Dissenters in the Parish of Ballykelly, which had been printed for Belfast printer John Hay in 1766 and reprinted by Magee in 1770, was reprinted in Salem, Massachusetts in 1771 and 1772 (although the latter is likely to have been a reissue) and in Newburyport (1798).

${ }^{61}$ David Manson, A New Primer; Or, Child's Best Guide (Philadelphia, PA: John Dunlap, 1770?).

${ }^{62}$ The Young Clerk's Vade Mecum: Or, Compleat Law-Tutor ([New York]: Belfast printed: New-York, reprinted by H. Gaine, 1776).
} 
R. Bailey in Philadelphia (1795), its imprint noting that it was written by 'John Tisdall, Notary Bublic [sic] of Belfast’. Also, a reprint of John Gough’s Practical Arithmetick in Four Books was printed in Wilmington by Peter Brynberg (1798) with the addition of 'an Appendix of Algebra, by the Late W. ATDINSON, of Belfast', perhaps having been written by W. Atkinson who was treasurer of Portadown Rangers in $1795 .{ }^{63}$ Evidently these publications sought to appeal to a market of readers for whom the mention of Belfast was a point of enticement, which suggests a likely appeal to a community of Ulster migrants.

While booksellers and printers in Philadelphia and New York responded to this demand for Belfast printed books, first, through importing and, secondly, through reprinting Belfast texts, those at work in the Belfast book trade had their own motivations for being involved with colonial booksellers. Belfast's ties with North American booksellers were part of a wider quest for prestige and standing. Printers such as Magee used their Philadelphia connections as a means of accessing original political material which was unavailable outside North America and which had the effect of augmenting the status and capabilities of Belfast printing, at a time when Belfast was vying with Dublin for greater power in the Irish book trade.

A case in point is Magee's reprinting of American political texts throughout the Revolutionary War. Magee’s American publications were not simply the latest reprinted editions from London - which were characteristic of Magee's corpus (until the 1770 period) and of the Irish trade in general - but included material that had been originally published outside London. He reprinted three texts which had been originally published in

\footnotetext{
${ }^{63}$ BNL, 16-19 Oct 1795.
} 
Philadelphia. These represented the culmination of his involvement with printers and booksellers there and helped to create Magee's position as Belfast's chief supplier and printer of American printed matter. During the years 1771-78 Magee published 15 publications that dealt with the highly topical subject of the deteriorating relations between the American colonies and England. Of this number, seven key texts can be confirmed as having been printed by Magee. These are Thomas Coombe's Sermon Preached before the Congregations of Christ Church and St. Peter's Philadelphia on Thursday, July 20, 1775 (1775); William Pitt's Speech on the 20th of January 1775 (1775); Abbé Raynal's Sentiments of a Foreigner, on the Disputes of Great-Britain with America (1775); Caleb Evans’ British Constitutional Liberty. A Sermon, Preached in Broad-mead, Bristol, November 5, 1775 (1776); William Smith’s Oration in Memory of General Montgomery, and of the Officers and Soldiers, who Fell with him, December 31, 1775 (1776); William Steel Dickson's collection of Sermons (1778?); and John Wesley's Compassionate Address to the Inhabitants of Ireland (1778).

The three texts which were originally published in America were Abbé Raynal's Sentiments of a Foreigner (1775), Thomas Coombe's Sermon Preached before the Congregations of Christ Church and St. Peter's (1775) and William Smith's Oration in Memory of General Montgomery (1776). Magee’s Philadelphia reprints championed the colonists' cause and argued that their right to resistance was self-defence. They contended that it was their entitlement to seek political representation: 'we ask not a superiority, we only claim an equality with our brethren', as Raynal reasoned. ${ }^{64}$ The three texts formed

\footnotetext{
${ }^{64}$ Raynal, The Sentiments of a Foreigner, on the Disputes of Great-Britain with America (Belfast: James Magee, 1775) p. 19.
} 
part of the American Revolutionary debates occurring at this time, in which the sense of interest and anxiety generated by the rupturing of Anglo-American relations was felt especially keenly in the town of Belfast. Belfast, as the centre of the Presbyterian community in Ireland, was especially sympathetic to the American colonists. Dissenters' opposition to unjust or oppressive statutes, which derived from their own experience of penal legislation, made them sensitive to the colonists' complaints concerning their lack of political voice. ${ }^{65}$ Northern Dissenters consequently denounced the war as 'unjust, cruel, \& detestable' and William Steel Dickson said in a sermon he gave in Belfast, 'there is scarcely a Protestant Family of the middle Classes amongst us who does not reckon Kindred with the Inhabitants of that extensive Continent'. ${ }^{66}$ So enthusiastic was the level of support among Ulster Dissenters (who cited commercial, cultural and religious reasons why they opposed the war and sympathized with their colonial counterparts), that the Belfast News-Letter championed the rights of the colonists. These sympathies were suggested most of all by the paper's reprinting of the Declaration of Independence (the Belfast News-Letter was the first newspaper to report the Declaration outside America). ${ }^{67}$ And in 1775-76 Belfast bookshops quickly filled up with texts relating to the American crisis, of which James Magee was the pre-eminent supplier in the north of Ireland ${ }^{68}$ In

\footnotetext{
${ }^{65}$ James E. Bradley, Religion, Revolution, and English Radicalism: Nonconformity in Eighteenth-Century Politics and Society (Cambridge and New York, 1990): 7.

${ }^{66}$ William Campbell, 'Sketches of the History of Presbyterians in Ireland' (1803), Presbyterian Historical Society of Ireland, Campbell MSS, p. 235; William Steel Dickson, Sermons on the Following Subjects. I. The Advantages of National Repentance. II. The Ruinous Effects of Civil War. III. The Coming of the Son of Man. IV. The Hope of Meeting, Knowing, and Rejoicing with Virtuous Friends, in a Future World (Belfast, James Magee, [1778?]): 45.

${ }^{67}$ See BNL, 20-23 Aug 1776.

${ }^{68}$ For Ulster Dissenters' support of the American colonies, see Ian McBride, Scripture Politics: Ulster Presbyterians and Irish Radicalism in the Late Eighteenth-Century Ireland (Oxford, 1998): 113-123.
} 
responding to this high level of interest, Magee used the contacts that he had established with the Philadelphia book trade in order to meet local demand for American political publications.

In the first instance, his contacts enabled him to reprint material that was seldom available elsewhere. For example, the Belfast reprinted edition of Sentiments of a Foreigner by Abbé Guillaunme-Thomas Raynal was the only reprinted edition of the book outside North America. This was a text which was excerpted from Raynal's Histoire Philosophique et Politique des Établissemens et du Commerce des Européens dans les Deux Indes (1772), first translated into English in London 1776. ${ }^{69}$ The work was printed by James Humphreys in March 1775 and reprinted by Magee on 11 April of that year. ${ }^{70}$ Given the shortness of the time-frame - Magee's reprint appeared less than five weeks after the work was first printed - Humphrey's text (either an advance copy or proofs) would have had to have been sent to Magee before the work went on sale in Philadelphia, since the passage across the Atlantic to Belfast is likely to have taken at least six weeks. ${ }^{71}$ This may have been performed with Humphrey's knowledge and consent, but there is also the possibility that the sheets used by Magee as the source of his copy were surreptitiously

\footnotetext{
${ }^{69}$ It was translated by J. Justamond and printed for T. Cadell in London in 1776. Hereafter, I use Histoire dans les Deux Indes as its short title. For a list of English translations of Histoire dans les Deux Indes see Appendix 2, 'French Books connected with the French Enlightenment Published in Ireland, 1700-1800' in Graham Gargett and Geraldine Sheridan (eds.), Ireland and the French Enlightenment, 1700-1800 (Basingstoke, 1999): 268-9.

${ }^{70}$ The dating of Humphrey's text has been ascertained by the advertisement, pp. [iii]-iv, which is dated 17 Mar 1775. Magee's reprint was printed and available for sale on 11 Apr See BNL, 11-14 Apr 1775.

${ }^{71}$ A journey between Larne and New York was a passage of 32 days, while the passage between Derry and Philadelphia took six weeks. BNL, 24-7 Nov 1778; Stephen A. Royle and Caitríona Ní Laoire, “Dare the Boist'rous Main": The Role of the Belfast News Letter in the Process of Emigration from Ulster, 17601800’, The Canadian Geographer/Le Géographe Canadien, 50, 1 (2006): 58.
} 
obtained before Humphrey's edition had even appeared in bookshops in Philadelphia. Such dealings were not unfamiliar among Irish printers. ${ }^{72}$

In reprinting the first English translation of Histoire... dans les Deux Indes, albeit only in excerpted form, Magee had provided a text that was not to be available in complete translation until the following year. He had reprinted a text that had originated not in London but in Philadelphia and evidently he made use of his Philadelphia connections in order to access Humphrey's edition in advance of its sale in America. Magee was demonstrating that he had the contacts and the capabilities to produce material relating to the American crisis that was among the latest publications and that he was not a small town provincial printer, slavishly deriving material from the metropolis.

Indeed, not simply content with having established connections with the Philadelphia book trade, nor with having made use of such contacts to produce material unavailable outside North America, Belfast printers purposely disclosed on imprints their intimacy with printers there. This can be illustrated in Smith's Oration in Memory of General Montgomery which Magee reprinted in 1776. In his reprint the title page confidently announced that it was 'Philadelphia: printed by John Dunlap, and, Belfast: reprinted, by James Magee, 1776 '. In Ireland Smith’s Oration was reprinted in Dublin by John Beatty and in Belfast by Magee, both in 1776. The inclusion of Dunlap’s name as the original printer occurred on the imprints of both these reprints. This explicit gesture of linking Magee with a specific Philadelphia printer was intended to augment Magee’s status

\footnotetext{
${ }^{72}$ There is the famous example of the Dublin pirated edition of Richardson's Sir Charles Grandison in 1753. See Pollard, Dublin's Trade in Books, pp. 88-9; Cole, Irish Booksellers and English Writers, pp. 11.
} 
but it also reflected back upon Philadelphia printing, which was growing in significance. Throughout the years of the American Revolution (1775-83) Philadelphia printers produced an output of works that was drawing closer to the total of the Dublin trade; according to the ESTC, they lagged behind Dublin printers by only 25 per cent. Magee's acknowledgment of Philadelphia as the place of original publication was not remarkable, since it was common for reprinted texts to indicate where the work was first printed. His inclusion of Dunlap's name as the original publisher was, however, distinctly unusual. No other of Magee's publications, numbering 377 in total, imitated this practice. ${ }^{73}$ In fact the word 'reprinted' occurred 415 times in pre-1801 American imprints, but only in 13 of those imprints was the first printer named. ${ }^{74}$ Bearing in mind that Magee's imprints were often ambiguous, the explicitness of the publication detail here is especially salient.

While there is some circumstantial evidence to suggest that Dunlap's name was known in Belfast, owing most likely to family connections, it appears that Magee’s naming of Dunlap was an attempt to associate his shop with Philadelphia, to affirm secure, tangible, even personal connections with the city. ${ }^{75}$ Magee was actively engaged in selling to his readers these ties with Philadelphia, which itself was a means of indicating the American

\footnotetext{
${ }^{73}$ I have calculated that Magee produced 377 works. It is certain, however, that Magee printed more titles than this. In this study however all calculations respecting Magee's career only take into account texts whose dating is certain. Publications where questions remain about the dating are not included in my calculations.

${ }^{74}$ This information was ascertained by performing a search of Early American Imprints (Evans \& Shaw Shoemaker online). I am grateful to James Green of the Library Company of Philadelphia for this information.

${ }^{75}$ Despite leaving his home in Strabane when he was a boy there were still extant family members of the Dunlap family in Ulster with whom John communicated from Philadelphia. This is revealed in the Dunlap letters held in Public Records office of Northern Ireland (PRONI). Local connections would explain this familiarity with Dunlap's name as Dunlap would not have been known as the printer of the Declaration of Independence at this point.
} 
sympathies of his publications, sentiments which were felt throughout Ulster and which are likely to have translated into readership sales. Also, this reflects the bourgeoning confidence of Belfast as a town. No longer was it content to follow that which was being propounded in London; Belfast sought the example of other cities in the provinces (Philadelphia especially) that were growing in commercial and political importance and which were challenging the primacy of London.

This case study of the book ties between Belfast and Philadelphia c. 1763-76 is important for scholarship on the history of the book, not least because there has been no previous study devoted to investigating the interchanges between the two book trades, but also because what can be extrapolated from it challenges some of the common assumptions held regarding Irish printing and Irish reprinted editions. For example, it has been an accepted view that the dissemination of Irish books across the Atlantic to cities such as New York and Philadelphia was driven by capitalist enterprise and that the cheapness of Irish reprints, allied with the high price of printing in America, compelled colonial booksellers to import Irish books. While this might account for the sale of Belfast and Dublin printed books in North America, it offers only a partial account. The complete picture is much more nuanced. The example of Hall's order to Magee has demonstrated that economic considerations were peripheral to other more pressing issues, such as, in his case, the desire to commence a new business relationship at a time of great stress in dealings with existing contacts.

Of greater significance still was the particular kind of reader that Hall was hoping to attract by means of this material: the sale of Belfast books in Philadelphia was driven by 
a rising demographic of Ulster immigrants, for whom Belfast texts were eminently familiar and resonant of home. The appeal to readers of Ulster-Scots extraction is foremost among the reasons why the publications of James Magee were requested, imported and reprinted in Philadelphia. It appears that Belfast editions were actually preferred here, indicated by Dunlap and Gaine’s reprinting of Belfast texts. One could argue further that colonial printers wanted to make the connections with Belfast explicit - Gaine's reprint of The Young Clerk’s Vade Mecum emphasized its Belfast heritage: ‘Belfast printed: New-York, re-printed by H. Gaine'. ${ }^{76}$

This chapter thus revisits the question of the importance of reprinted editions in the colonial market. In a culture in which, as Raven has noted, 'Books were notable luxury goods - totems of respectability and conveyors of metropolitan thought', imported books in the colonies were much sought after commodities. ${ }^{77}$ Indigenous publications were regarded as homespun and colonial gentlemen showed the greatest pride of possession in the imported book; London editions carried the ultimate prestige. ${ }^{78}$ This portrayal of the high status and preference among readers for London editions must, however, be contested when we consider the demand for Belfast books in Philadelphia. While first editions and fine editions are traditionally celebrated - we imagine that readers must have sought them - reprints, it must be remembered, are actually indicators of cultural preferences. Belfast reprints that were imported to North America therefore were acquired because readers sought these particular editions. They were redolent of Belfast/Ulster by means of their

\footnotetext{
76 See note 59.

${ }^{77}$ Raven, London Booksellers and American Customers, p. 8.

${ }^{78}$ Barber, 'Book Imports and Exports in the Eighteenth Century', pp. 95-6.
} 
content but especially in their typography and design, and thus offered an advantage over any other edition. They offered nostalgic meaning and value to a market of Ulster-Scots readers hungry to hold on to, or to recapture, the memories and identity of home. Of course, the same analysis might be applied to other Irish reprints sold in an American context; they would have had undoubted significance for the pockets of Irish migrants now living in the New World, who are likely to have been among the readers of this kind of material.

This reading of events tends to shift the focus away from the economic merit of Belfast and Dublin reprints and locates their significance rather within a cultural context. Such a view is consonant with Sher's assessment of the contribution made by Irish printers and Irish reprints in America in which he emphasized that Irish printers and booksellers, by means of their reprints, were vital agents in disseminating Scottish Enlightenment culture to America. But if we are inclined to think of printers such as Magee as being in this mould, and that by means of his reprints he was disseminating not just books but fragments of cultural and national identity to a community transposed to a new homeland, we are in danger of overlooking the other cultural significance of his reprints - namely, their impact on a Irish market. For these reprints were ultimately an expression of the rising confidence of Belfast, both as a town and as an important printing hub.

By means of his connection with the Philadelphia and (possibly) New York book trades, Magee was able to sell his books, but he was also able to access new American works. For example, in March 1775 Magee advertised an impressive consignment of polemical tracts and pamphlets, newly 'imported from America'. These imported publications, seven in total, included titles such as Free Thoughts on the Proceedings of 
the Continental Congress (1774); The Congress Canvassed; Or, An Examination into the Conduct of the Delegates (1774) and A View of the Controversy between Great-Britain and Her Colonies (1774). ${ }^{79}$ His contacts with North American booksellers assisted him in terms not only of what he could import, but also what he could reprint. His reprinting of American political texts forged links (commercial and ideological) with the colonies and rooted Irish men and women firmly in an imperial dispute in which they, like the colonies, existed at the periphery of the empire. Moreover, by taking greater publishing risks, and reprinting material from places other than London, Magee was endeavouring to construct an image of himself as a far-reaching printer, quite literally in the case of his ties with the Philadelphia book trade. In flagging up the names of Philadelphia printers (in this way, indicating connections to his readers), Magee self-consciously moved away from the limiting provincialism of Irish town printing and consolidated his reputation as an innovative and progressive printer of Dissenting tracts and polemics. The result was that Belfast printing, by means of Magee, was moving from the margins. This increasing selfassurance can be witnessed in Magee's decision to offer competing editions to the Dublin trade at this time, including single-handedly offering a challenge to conger publications of the newly formed Dublin Company of Booksellers. ${ }^{80}$ No longer content to issue word-forword reprints from the metropolis and operate as a printing dependency of London, Belfast printing was renegotiating its status as a small town trade and was consciously occupying

\footnotetext{
${ }^{79}$ BNL, 7-10 Mar 1775.

${ }^{80}$ For details of this challenge to the Dublin trade, see Michael O’Connor, 'James Magee (1707-1797) and the Belfast Print Trade, 1771-1781’ (unpublished Ph.D. thesis, Queen’s University Belfast, 2007): 164-69.
} 
a more prominent place both nationally and internationally. Magee’s connections with the colonial book trade, particularly his relationship with booksellers and printers in Philadelphia, was pivotal to this emerging confidence and offered Belfast booksellers valuable and new-found leverage within the Irish book trade. 